\title{
Archives in the Internet Space
}

\author{
MIKHAIL V. LARIN, PH.D., PROF. \\ Director, All-Russian Scientific and Research Institute for Archives and Records Management (VNIIDAD), \\ Russia, Moscow, 117393, Profsoiuznaia ul., 82 \\ e-mail:www.vniidad.ru; larin@vniidad.ru
}

\section{Archives in the Internet Space}

\begin{abstract}
Presentation of information resources of the Russian archives in global information networks is an actual task of the current stage of archives management development. This task is a part of the Program of archives management informatization in the Russian Federation. The report highlights results of a project on creating an information portal „Archives of Russia“. Infrastructure of the portal, its main aims, formation of information resources are considered in it. Basic methodical approaches to the portal's structure, forms and methods of work on filling the resource and support it in a working order are also reflected in this report. The main purpose of the portal is to give users additional opportunities to get access to archives, finding aids, specific records and their collections based on modern information technologies. The author describes principal methods for enhanced interaction of archives and their users in the process of obtaining necessary new information, legal basis for such cooperation, fulfillment of social and legal, and case requests of users. Major forms of archival records' usage: central fund catalogue, state register of unique records of the Russian Federation Archival fund, guides to the Russian archives, electronic inventories of federal archives, online - projects exhibitions, electronic library, services to users in electronic form are mentioned in the report. Portal „Archives of Russia“ gives an opportunity to provide direct access to 85 regional archival resources and allows for a possibility of its expansion and additions. The author also presents a related project for creation of a virtual reading room in federal archives. As a part of this project it is expected to provide online - user access to archival records, including possibility of copying them. These projects will greatly enlarge the abilities of users to archives' access by using modern information technologies and enable greater participation of the Russian archives in the world information space.
\end{abstract}

Key words: archives, archival record, portal, information resource, information technology

\section{Gli archivi nello spazio internet}

SINTESI

La presentazione di risorse informative sugli archivi russi nel network dell'informazione globale è il compito da affrontare nel presente momento dello sviluppo della gestione degli archivi. Questo impegno fa parte di un programma di informatizzazione della gestione degli archivi della Federazione russa. L'articolo mette in luce i risultati di un progetto volto a creare il portale informativo "Archivi di Russia”. Vi si considerano l'infrastruttura del portale, i suoi obiettivi principali, la formazione delle risorse informative ed i metodi di lavoro. Sono anche esposti nell'articolo i metodi di approccio basilare alla struttura del portale, le forme ed i metodi e l'ordine di lavoro. Scopo principale del portale è fornire agli utenti opportunità ulteriori di accesso agli archivi, agli strumenti di ricerca, a specifici documenti e alle loro raccolte basate sulle moderne tecnologie informatiche. L'autore descrive i principali metodi per aumentare l'interazione fra gli archivi e la loro utenza nel processo di ottenimento delle necessarie informazioni, delle basi legali per una tale cooperazione, per l'attuazione sociale e legale, e le casistiche di richieste degli utenti. Si menzionano nell'articolo le principali forme di utilizzo archivistico: catalogo centrale dei fondi, registro di stato dei singoli documenti del fondo archivistico della Federazione russa, guide agli archivi di Russia, inventari elettronici degli archivi federali, progetti di mostre online, biblioteca elettronica, servizi agli utenti in forma elettronica. Il portale "Archivi di Russia” fornisce un'opportunità di dare accesso diretto alle 85 risorse archivistiche regionali e consente la possibilità della sua espansione e di ulteriori aggiunte. L'autore presenta anche un progetto collegato per la creazione di una sala di lettura virtuale negli archivi federali. Ci si aspetta che una parte di questo progetto fornisca all'utenza accesso online ai documenti archivistici, inclusa la possibilità di copiarli. Questi progetti amplieranno grandemente le capacità degli utenti di accedere agli archivi tramite l'utilizzo di moderne tecnologie informatiche e consentirà una maggior partecipazione degli archivi russi allo spazio informativo mondiale.

Parole chiave: archivi, documenti archivistici, portale, risorse informatiche, tecnologia informatica 


\section{Arhivi na internetu}

\section{IZVLEČEK}

Predstavitev informacijskih virov ruskih arhivov v globalnih informacijskih omrežjih je pomembna naloga na sedanji stopnji razvoja upravljanja arhivov. Ta naloga je del programa za informatizacijo upravljanja $\mathrm{z}$ arhivi $\mathrm{v}$ Ruski federaciji. Prispevek obravnava rezultate projekta izdelave informacijskega portala „Arhivi Rusije“. Obravnava infrastrukturo portala, njegov glavni cilji in oblikovanje informacijskih virov, prav tako pa tudi osnovne metodološke pristope $\mathrm{k}$ strukturi portala, oblike in metode dela za vnos podatkov in podporo delovanja. Glavni namen portala je uporabnikom, na osnovi sodobnih informacijskih tehnologij, omogočiti dodatne možnosti dostopa do arhivskega gradiva, informativnih pomagal, posameznega arhivskega gradiva in zbirk ter fondov. Avtor opisuje glavne metode za večjo interakcijo arhivov in njihovih uporabnikov v postopku pridobivanja potrebnih informacij, pravno podlago za tako sodelovanje, izpolnjevanje socialnih in pravnih ter drugih zahtev uporabnikov. Prispevek navaja glavne oblike uporabe arhivskega gradiva: centralni katalog, register edinstvenih dokumentov arhivskega fundusa Ruske federacije, vodnike po ruskih arhivih, elektronske inventarje zveznih arhivov, projekte spletnih razstav, elektronske knjižnice ter storitve za uporabnike. Portal "Arhivi Rusije“ omogoča neposreden dostop do gradiva, ki ga hranijo v 85 regionalnih arhivih, pri tem pa je možna tudi njegova širitev in dopolnitev. Avtor predstavlja tudi povezan projekt za vzpostavitev virtualne čitalnice v zveznih arhivih. V okviru tega projekta bo uporabnikom zagotovljen tudi spletni dostop do arhivskega gradiva, vključno z možnostjo kopiranja. Ti projekti bodo bistveno povečali možnost za dostop do arhivskega gradiva z uporabo sodobnih informacijskih tehnologij prav tako pa bodo omogočili večjo udeležbo ruskih arhivov v okviru svetovnega informacijskega prostora.

Ključne besede: arhiv, arhivski zapis, portal, vir informacij, informacijska tehnologija

\section{Архивы в интернет - пространстве}

\section{АННОТАЦИЯ}

Представление информационных ресурсов российских архивов в глобальных информационных сетях яв-

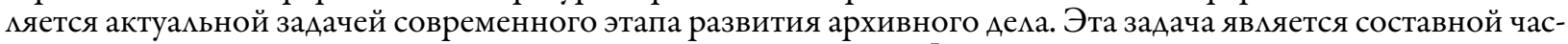
тью Программы информатизации архивного дела Российской Федерации. В докладе освещаются результаты проекта создания информационного портала «Архивы России». Рассматриваются инфраструктура портала, его основные задачи, раскрываются направления формирования информационных ресурсов. В докцаде отражаются основные методические подходы к построению портала, формы и методы организации работы по наполнению ресурса и подАержки его в рабочем состоянии. Раскрывается главная цель создания Портала - дать дополнительные возможности пользователям архива получить доступ к архивам, научносправочному аппарату и конкретным документам, их коляекциям на базе современных информационных технологий. В докладе рассмотрены основные методы активизации взаимодействия архивов и их пользователей в процессе получения необходимой новостной информации, правовых основ такого взаимодействия, исполнения социально-правовых и тематических запросов пользователей. В докмаде рассматриваются основные формы использования архивных документов: центральный фондовый каталог, государственный реестр уникальных документов Архивного фонда РФ, путеводители по российским архивам, электронные описи федеральных архивов, online-проекты выставок, электронная библиотека, услуги пользователям в электронном виде. Портал «Архивы России» дает возможность осуществить непосреАственный доступ к 85 региональным архивным ресурсам и допускает возможность его расширения и дополнения. В докладе рассматриваются также смежный проект создания виртуацьного читального зала в федерацьных архивах. В рамках этого проекта предполагается обеспечить online-доступ пользователей к архивным документам, включая возможность их копирования. Аанные проекты значительно расширяют возможности пользоватемей в доступе к архивам с использованием современных информационных технологий и позволяют расширить участие российских архивов в мировом информационном пространстве.

Ключевые слова: архив, архивный документ, портал, информационный ресурс, информационная технология

Representation of archival resources in global information networks is an actual problem of archival activity development in different countries at present. This task was greatly reflected in the materials of the ICA International Congress on Archives, which took place in 2012 in Australia. These problems are broadly covered also at the conferences, held by the International Council on Archives at forums of the International Archival Day of the International Institute of Archival Science in Trie- 
ste and Maribor. And at last, many reports of the next world forum of archivists in Seoul will be devoted to the problems of work with electronic records and use of global telecommunication networks.

The experience of a number of national archives of different countries on presentation of archival records in global information networks is well known. From this point of view, approaches of NARA, Bundesarchiv, the Australian archives and others to policy and methodology solutions of the problem on interaction of archives with environment are of great interest.

Representation of archival information resources in the Internet is a vital problem of archival activity development in different countries nowadays. In his report „Archives in the world of social networks" David Ferrero, the head of National Archives and Records Management (NARA) from the USA, pointed out that in modern world the social networks are both sources and consumers of archival records information, and archivists must take into account this content in their work (Ferriero, 2012). The main trends and achievements of informatization policy of the Russian Federation were presented in the speech of O. V. Naumov, the deputy head of Federal Archival Agency, „The Russian archives in the virtual space: present and future". Dr. O. V. Naumov emphasized the project of Comintern Archive computerization as the first experience of records digitization and access to special documentary collections by means of the Internet (Naumov, 2012). At the Congress also the Japanese archivists showed their experience of creating the first digital archives under the National Archives of Japan - the Japanese Center of Asian Historical Records (JACAR). It includes more than 25 million images of records (Hirano, 2012).

The experience of national archives from different countries on presentation of archival records in global information networks is world famous. The approaches of Bundesarchiv (Germany), NARA (the USA), the Australian, the Slovenian archives and others are worth of great attention as far as decisions of policy and methodology problems of archives interaction with environment.

For example, in the Federal Archives of Germany (Bundesarchiv) a special division „Digital archives" was created. It integrates digitized images of archival funds of records with usage of new information technologies, access to which is organized without visits to archives. About 10 million electronic files are stored in „Digital archives“ now. At the $8^{\text {th }}$ ICA European Conference on digital archiving ECA-2010 Michael Hollmann, the president of the Federal Archives of Germany, made a report „Electronic archives of the Federal Archives of Germany“. It contains concepts of components, al ready realized by now, and also perspective plans on development of electronic archives of the Federal Archives of Germany (Hollmann, 2010).

The Electronic Records Archives (ERA) within the National Archives and Records Management (NARA) is successfully functioning since September, 2011. It was developed by the American archivists. According to the data for March, 2014, ERA contains more than 380 TB of electronic records, including records from many federal departments, the Congress of the USA and materials of the Presidential Administration (Knowles, 2015).

The work and experience of the Australian archivists are given in the report of S. Thompson, K. Moir and J. Hanisch „The digital imperative: catching up and staying ahead of the digital revolution“. The Australian and international experience show that development of technical progress and social changes, leading to the serious risks, concerning information stability, advance the process of information and records management. Without effective management of digital information and records the organizations will have problems in the work with a large number of various digital information, which they process every day (Thompson, Moir and Hanisch, 2012).

The project „Creation of Electronic State Archives of Slovenia“ is an example of comprehensive approach to creation of electronic archives. The e-ARH.si project was submitted in the report of B. Cvelfar, director of the State archives of the Republic of Slovenia, at the $7^{\text {th }}$ annual International Archival Conference of Mikrografija company in 2015. While creating the archives the following integrated approach was used: unification of digitized and digital records of the State archives and 6 regional archives into a unique digital resource, located in the territory of the Republic of Slovenia (Cvelfar, 2015). And in this case the portal option of representation of archival information was also applied.

Large international and all-European projects on creation of digital archives are presented by 
various information resources. I would like to note, first of all, Portal of Europe archives, which includes more than 30 institutions - partners (this resource, financed by the European Commission project groups APEnet and APEx, provides free access to digital content to users). One can also call the portal of the European Digital Library Europeana including about 15 million objects (according to the data for 2015) and audiovisual collections from 1500 cultural institutions of 27 European countries (Bredenberg and Jagodzinski, 2014).

In 2013 within the Conference of XXIII IIAS International Archival Day Grazia Tato, director of the Autumn Archival School, made a report „The Italian national archival system (SAN): new portals and the contribution of the State archives of Italy". It contains the information about experience of seven portals' creation within archival information SAN system (Tatò, 2013). At the last Conference of XXV IIAS International Archival Day a project from Croatia on disposition of photographic images in the virtual space was submitted (Hedbeli and Mokrović, 2015). The authors stated about the approach to virtual representation of a photo collection in the Internet - space, and also pointed out the difficulties in management process of such collections in real and virtual conditions. It is obvious that the portal option of archival information representation in a global network is one of the main questions now.

The Russian Federation is also has one of the largest archival systems in the world. Its scale, complexity of structure determined the organizational forms of the Russian archives management. Taking into account state significance of archives, on April 4, 2016, the archival service began to submit directly to the President of the Russian Federation (Act On the Federal Archival Agency, 2016). The executive body of the service is the Federal Archival Agency, which carries out the activity in interaction with other federal executive authorities, executive authorities of subjects of the Russian Federation, local governments, public and other organizations. The main tasks of the Federal Archival Agency are the following:

- provision of state services in archival activity;

- state registration and control of records of the Russian Federation Archival fund, conducting the State register of unique records of the Russian Federation Archival fund;

- enforcement of rules on storage, acquisition, control and use of archival records.

Fifteen federal state archives, the All-Russian Scientific and Research Institute for Records and Archives Management (VNIIDAD), making the major link in the system of archival institutions of Russia and being scientific and information, cultural and historic centers of national and international significance, are directly subject to the Federal Archival Agency. Six federal archives are included into the State code of extra - valuable objects of cultural heritage of the Russian Federation peoples.

The Russian Federation subjects have functioning governing bodies of archival activity, under the jurisdiction of which state (regional) and municipal archives are. The Federal Archival Agency provides methodical support to them. Archival activity as an activity of public authorities, local governments, organizations and citizens in storage, acquisition, control and use of records of the Russian Federation Archival fund and other archival records, provides possibility of historical experience usage for reasonable administrative decision - making, definitions of political, economic, social and other priorities, formation of predictions and programs of society and state development. The Russian Federation Archival Fund contains more than 609 million units of storage (over 42,5 million units of storage in federal archives are among them) from the XI century up to now. It is a historically developed and permanently supplemented set of archival records, reflecting material and spiritual life of society. They are of historical, scientific, social, political, economic and cultural significance, being an integral part of historical and cultural heritage of the Russian Federation peoples. These records include the data, necessary for providing state sovereignty and national security of Russia, its foreign policy activity, effective functioning of all government structures, development of domestic science and culture. Preservation, replenishment and use of the Russian Federation Archival fund records are provided also by more than 200 state regional archives, records storage centers, 2357 municipal archives and about 126000 archives of state and non - state organizations.

Use of the Russian Federation Archival fund records is a component of the Program of informatization of the Russian Federation archival activity, aimed at realization of comprehensive expansion 
of general public access to archival records. Portals ideology is the evidence-based technological decision, used for creation of archival information resources of Russia. It is obvious that the portal is the information environment, providing protected personified web interface by means of which users (staff of archives and external audience) have access to necessary information and services according to the carried-out tasks and access rights.

The Russian archival portals have passed a long way of evolution. The first one, realized in 2002, became a branch site „Archives of Russia“. At that time it was a huge break in technology and publicity of archival activity. Suffice it to say that archival branch was the first in the country to represent in the Internet full information on all federal archives, governing bodies of archival activity and state archives of 83 subjects of federation. The site included main archival directories, legal and normative and methodical branch documentation in the site. Articles from professional journals were published on the website and news - in online regime.

The first actually technological portal decision - the Central Fund Catalogue (TsFK) - the information resource, providing information on archival funds, stored in archives of Russia, appeared on the portal "Archives of Russia" in 10 years in January 2012. The emergence of this resource is connected with a new version of uniform branch program complex „Archival Fund“, developed on web technologies, and put into operation. It was created for automated registration and finding aids system by all archives of the Russian Federation. It allowed us in automated regime "to collect" data files from all archives of the country and to represent them in the integrated information resource.

Data on 917110 funds from 13 federal archives and 2234 state and municipal archives of 59 of the Russian Federation subjects were included into TsFK for the four years period of its functioning. It is more than $65 \%$ of total amount of the Russian Federation Archival Fund (according to the data for January 1, 2016) (The Central Fund Catalogue, 2016).

The Central Fund Catalogue has „official“ interface by means of which the staff of Rosarkhiv can control processes of resource filling, receive summary statistics and „public“ interface, presented in the Internet and aimed for use by wide audience.

Similar projects are carried out at the regional level. For example, „Information Resources of the Pskov Region“ portal, representing integrated finding aids system of five regional archives, was created in the Pskov region (Information Resources of the Pskov Region, 2016).

It is obvious that in these portal decisions we study the question only about mechanisms of integration and public presentation of registration data and finding aids system (NSA). But such functionality is not enough today. So, at the beginning of 2016 the Federal Archival Agency set the task of development of new architecture of basic program complex „Archival Fund“ on the basis of the portal decision with cloud technologies application. Within this program complex the principles of automation of all intra - archival business processes in all archives of the country will have to be completely realized. It means that each archives and each employee of archives according to their functions will receive a personal point of access to the portal for realizing the functions and filling uniform information resource. Thus, creation of full - scale portal solution of centralized, split - level management of the Russian Federation archives activity and of a state of Archival Fund of the country on the basis of information management principles will be complete. Of course, the question is not about organizational management of all archives of the country from the center. In our case we speak about a perspective of creation of uniform information infrastructure of country archives, that will give the chance of the best use of archives not only by users within the country, but also by foreign researchers.

This is the perspective which full realization is one of the aims of archival activity informatization in Russia. Achievement of this purpose is carried out step by step. So, there are the following realized portal decisions as the portal "Records of the Soviet Era", in which electronic copies of four thematic documentary complexes are presented: „Supreme bodies of party government of the Soviet era (materials of the Politburo of the Central Committee of the Russian Communist Party (bolsheviks) (TsK RKP(b)) - Communist Party of the Soviet Union (bolsheviks) (VKP (b)) for 1919 - 1932“; „Archives of Komintern; Personal fund of I.V. Stalin"; electronic copies of records from the fund of the USSR State Committee of Defense (GKO) (1941-1945) - in total more than 1 million 200 thousand pages from the Russian State Archives for Social and Political History (RGASPI). Over time it is plan- 
ned to put also electronic copies of thematic complexes from other federal archives of the Russian Federation and copies of audiovisual records on the portal. It will allow to create a multimedia resource, representing different types and kinds of records in digital environment (Records of the Soviet Era, 2016).

Taking into account that functionality of this resource for users is very limited technologically, on the basis of portal approach Rosarkhiv is going to carry out a project of creating an integrated virtual reading room. Thus, users will receive the expanded services which are actually replacing work of researcher in the reading room.

There is an experience of creation and functioning of a similar reading room within the region in the Russian Federation. So, a unified virtual reading room, representing finding aids system (NSA) and electronic copies of thematic complexes of records (registers of births) from seven city archives is functioning at the Archival Committee of St. Petersburg (Archives of St. Petersburg, 2016).

One more project, which is worth to mention: upgraded version of all - branch portal „Archives of Russia", presented in January of this year. The peculiarity of the version is that now each regional governing body of the Russian Federation archives activity, each state and municipal archive has an opportunity to keep their own page independently. So, the principle of crowdsourcing - filling of unified information system by the hands of archivists from regions is realized in practice (Archives of Russia, 2016).

To make a short conclusion it should be pointed out that active application of modern information technologies is changing the image of archival system significantly, turning it into a high - tech socially important establishment, a center of science and culture, open for wide audience. Thus, the portal way of realization of access to archival information resources is of great significance both for acquaintance to finding aids system of archives, and for use of archival records irrespective of a place of their physical location. Besides, researchers have an opportunity to receive electronic copies of archival records. The portal can also be applied for usage of uniform technology of archival fund records registration and management of archives information systems on the integrated methodical and technological base, providing the unified approach to information support.

\section{References}

Зарубежный опьт управления электронными документами и организачии их архивного хранения. Аналитический обзор. Под редакиией М.В. Марина. (2014). Федеральное архивное агентство. М., ВНИИААА.

Указ Президента Российской Федерачии от 04.04.2016 «О Федеральном Архивном Агентстве». Офичиальньцй сайт Федерального Архивного Агентства: http://archives.ru/press/04-04-2016.shtml.

Tatò, G. (2013). The Italian National Archival System (SAN-Sistema Archivistico Nazionale Italiano): the New Portals and the contribution of the State Archives of Trieste. In: Atlanti. Review for modern archival theory and practice. Special edition. In honorem Charles Kecskemeti, Trieste - Maribor, pp. 213-222.

Hedbeli, Z., Mokrovic, N. (2015). Managing a Photograph Collection: ARKzin photo archive case study. In: Atlanti. Review for modern archival theory and practice. Trieste - Maribor, Vol. 25, N. 1, pp.131-140.

Ferriero, D. (2012). Archives in a World of Social Media. Report at the XVII International Congress on Archives. International Council on Archives. Australia, Brisbane. August 20-24, 2012. Available at: http://www.archives. gov/about/speeches/2012/8-21-2012.html.

Naumov, O. (2012). Russian archives in the Virtual Space: present and future. Report at the XVII International Congress on Archives. International Council on Archives. Australia, Brisbane. August 20-24, 2012. Avaliable at: http://ica2012.ica.org/files/pdf/Full\%20papers\%20upload/ica12final00251.pdf.

Hirano, K. Digital Archives for Historic Research and International Understanding. Report at XVII International Congress on Archives. International Council on Archives. Brisbane, Australia. August 20-14, 2012. Avaliable at: http://ica2012.ica.org/files/pdf/Full\%20papers\%20upload/ica12Final00335.pdf.

Hollmann, M. Das Elektronische Archiv des Bundesarchivs. Report at the 8th European Conference on Digital Archiving (ECA 2010). Geneva. April 28 - 30, 2010.

Knowles, B. Electronic Records Archives. Roger Williams University. School of Architecture, Art and Historic 
Preservation. Historic Preservation Theses. Spring 2015, 97 pages. Avaliable at: http://docs.rwu.edu/hp_theses.

Thompson, S., Moir, K., Hanisch, J. The digital imperative: Catching up and staying ahead of the digital revolution. Report at the XVII International Congress on Archives, International Council on Archives. Brisbane, Australia. August 20-14, 2012.

Cvelfar, B. Establishment of Slovenian electronic archive. The National Archives of the Republic of Slovenia. Report at the $7^{\text {th }}$ Mikrografija Conference. Ljubljana. Slovenia. October 21, 2015.

Bredenberg, K., Jagodzinski, S. Archives Portal Europe - A Challenge of Harmonization and Outreach. $9^{\text {th }}$ European Conference on Archives. Girona 2014.

Act of the President of the Russian Federation from April 4, 2016, "On the Federal Archival Agency".

The Central Fund Catalogue. Available at: http://cfc.rusarchives.ru/CFC-search/Search/Info.

Portal "Information Resources of the Pskov Region". Available at: http://document.archive.pskov.ru.

Portal "Records of the Soviet Era". Available at: http://sovdoc.rusarchives.ru/\#search.

Archives of St. Petersburg. Available at: https://spbarchives.ru/web/group/paid_access.

Portal „Archives of Russia”. Available at: http://www.rusarchives.ru/state/byrat/ministerstvo-kultury.

\section{SUMMARY}

The main methods of interaction of archives and their users in the Internet space are taken up in the report. The author made the analysis of publications in which world experience of this task's solution is carried out. There are various examples of archival information' presentation in the Internet in the form of sites, databases and portal decisions in this scientific report. The tendency of expansion of archival information portal presentation under present conditions is revealed here. This tendency is confirmed with skilled developments of the Russian archivists. At the level of the Federal Archival Agency the project is fulfilled as far as a portal way of access to archival information resources for users both for acquaintance to finding aids system of archives, and for use of archival records irrespective of a place of their physical location. Owing to the portal researchers have an opportunity to receive electronic copies of archival records. The portal will also be used for application of uniform technology of archival fund records registration and management of archival information systems on the integral methodical and technological base, providing the unified approach to information support. The allied project of creating a virtual reading room of federal archives in the portal is also viewed in the report. Within this project it is supposed to provide online-access to archival records for users, including a possibility of their copying. These projects greatly expand opportunities of users in access to archives with use of modern information technologies and allow to extend participation of the Russian archives in the world information space.

Typology: 1.04. Professional Article

Submitting date: 21.01.2016

Acceptance date: 20.02.2016 
